UDC 636.4.082

(C) 2016

\title{
Selection assessment of productivity of pigs of foreign parentage
}

\author{
V. Zeldin, \\ Candidate of Agricultural Sciences \\ State Institution Institute of grain crops of NAAS
}

The purpose. To determine productivity of pigs of foreign parentage and to generate in herd economically expedient genealogical groups of animals of the basic herd. Methods. Productive qualities of pigs of Irish parentage of breeds Landras and Yorkshire were studied according to demands [5] and some innovative methods. Processing of experimental data [6] was carried out. Results. Pedigree qualities of 238 sows of breed Landras and $\mathbf{2 7 0}$ of breed Yorkshire of Irish parentage are studied. It is fixed that the part of animals of leading group in breed Yorkshire makes 29,5, and in breed Landras - 24,6\%. Average level of fertility of sows of breed Yorkshire in conditions non-pasture content is $10,3 \pm 0,53$ piglets. Oscillation of fertility among different genealogical groups is within the limits of $9,9 \pm 0,25 \ldots 10,8 \pm 0,31$. Conclusions. The expediency of application of index procedure of determination of general breeding value of pigs and separate attributes of their productivity is confirmed.

Key words: sow, leading group, reproduction, index, carcass grade.

The modern state of pork production in Ukraine is characterized by the wide use in reproduction of herds of animals of foreign breeding or their Ukrainian reproduction. Earlier studies have shown that animals in the meat production direction compared to domestic ones are more sensitive to the harsh conditions of abstinence, lack of insulation, dry type of feeding and imbalance of dietary nutrition [4]. The situation is complicated by the lack of manageability of the breeding processes by the relevant state structures, which, for objective reasons, already have little influence on the expediency of introducing improved genotypes from abroad to the country [2].

At the same time, in these economic conditions, farms with a highly mechanized level of pork production require animals that are adapted for long-term exploitation, which is determined by the level of fertilization of sows in one's in clination, stable high fertility from farrow to farrow, strong legs and ratites and meatiness levels carcasses $60 \%$ and more. That is why the objective selection assessment of existing genotypes of pigs of complex genealogical design that has already been created in farms is due to the objective selection and necessitates an assessment, which is completely and difficult to do in accordance with existing requirements in the field $[9,10]$. Solving the problem of objective assessment of animals to determine their breeding value will provide the opportunity for further development of economically expedient pig breeding systems [5, 7]. Thus, the problem of efficient use in special economy pigs production of animals of foreign origin and determines the direction of our research.

The aim of the research was to determine the productivity level of the Irish pigs of Landrace and Yorkshire breeds in the conditions of the special economy pork production company LTD «Expert-Agrotrade» of the Dnipropetrovsk region, with the subsequent formation in the herd of economically feasible genealogical structures of pigs, breeding and selection systems for young animals of a model type of body structure and productivity for reproduction of the herd in the future.

Materials and methods of research: the subject of the research was the animals of the Landrace and Yorkshire breeds of Irish origin. The assessment of pigs was determined according to the requirements [11] and innovative techniques. The retention and feeding of pigs corresponded to the zootechnical standards. Statistical processing of experimental data was performed by G.F. Lakin [12]. 
Results of the research: the breeding qualities of 238 landraces and 270 species of Irish breed of sows were studied. Taking into account the release of animals, estimates of the level of productivity of the uterus in the flock as of 01.01.2015, there were 214 main sows of the Landrace genus and 233 Yorkshire breeds.

It was established that the specific gravity of animals of the leading group in the breed of Yorkshire is $29,5 \%$, Landrace $-24,6 \%$. The genealogical structure of the breeding stock in both breeds is arbitrarily represented by 7 families of animals, of which the most numerous are the family Rima (Yorkshire) and Hueberg (Landrace), respectively, 52,1 and $34,2 \%$ of the total number of animals.

At the same time, there is the thought of M.A. Kravchenko, that selection work with families is an element in breeding lines, and there is no separate breeding for families not related to breeding along the lines [8]. At the same time, the scientist questioned, according to the results of numerical studies, the availability of genealogical structures in pigs in the systematic of Zavadovsky M.M.

The analysis of the experimental data obtained indicates that the average fertility rate of the sows of the Yorkshire breed under the conditions of their abstinence in the special economy was 10,3 $\pm 0,53$ piglets. Fluctuations in fertility among various genealogical groups of sows were in the range of 9,9 $\pm 0,25-10,8 \pm 0,31$. It was established that the probability of the mean difference in fertility at the comparison began to be observed in cases where the difference in the sign between the two groups was at them not less than 0,9 piglets at minimum values of the number of degrees of freedom 13. The average ration score in the group $(n=69)$ was $3,81 \pm 0,049$ at the limits of the index $3,74 \pm 0,049-3,85 \pm 0,201$, which corresponds to the class "elite". However, in assessing animals by the method of the BLUP, the fact of greater differentiation according to the level of their breeding value of animals in groups was established.

Thus, in the parent lines the average value of the BLUP index was 103,88 $\pm 2,59$ with the limits of 62,11152,44 , in maternal lines, respectively, $97,24 \pm 2,37(49,95-156,61)$. It was found that the ratio of the maximum value of the index BLUP to the minimum in the parent lines was as 2,45: 1 , and in maternity $-3,14: 1$, which in general confirms the fact of a sharp non-equality of the breeding stock in the data of the structural groups of the herd by the level breeding value of breed animals Yorkshire.

Analysis of data on the productivity level of Landrace pigs fully reflects the situation with the level of selectivity and the breeding value of breeds of Yorkshire breeds. Thus, the genealogical structure of the leading group of pigs of the Landrace species economy is represented by the uterus of 6 families, the number of which is within $5-15$ head. The fertility of the uterus is $10,3 \pm 0,17$ on average, with an average limit of 10,0 (Gannet family) $-10,5$ (Hueberg, Naera). The tribal value, determined by the average punitive ball, was $3.86 \pm 0,024$ with an average of 3,78 (Gannet family) - (Missl family).

By the index BLUP (parent lines) the average indicator was 94,26 $\pm 2,13(\lim 61,32-142,78)$ ), in maternal lines $92,10 \pm 144,6(\lim 65,74-130,76)$.

It has been established that in both breeds in the groups of leading sows also a breed value of animals has certain heterogeneity of the livestock. Thus, the ratio of the magnitude Min: Max in the groups was 1: 2,33 and 1:19 (respectively, in the Yorkshire and Landrace breeds). It should be noted that when assessing animals in classes [11], it was found that experimental sows were classified as "elite", but this does not reflect the existing objective difference between animals in terms of pedigree value. Thus, the earlier made M.A. Kravchenko conclusion that there is no difference between conventional genealogical groups is partly confirmed.

We determined that the mean value of the BLUP (parent lines) was 104,69 at $\delta=13,69$ and $x_{\max }=146,07 x_{\min }$ $=62,11$ units of ind. For the BLUP (maternal lines), the average index value was 97,24 for $\delta=16,66$ at $x_{\max }=$ 156,61 was equal to $x_{\min }=56,65$ unit of ind. On figures 1,2 show curves for the distribution of BLUP index values. 


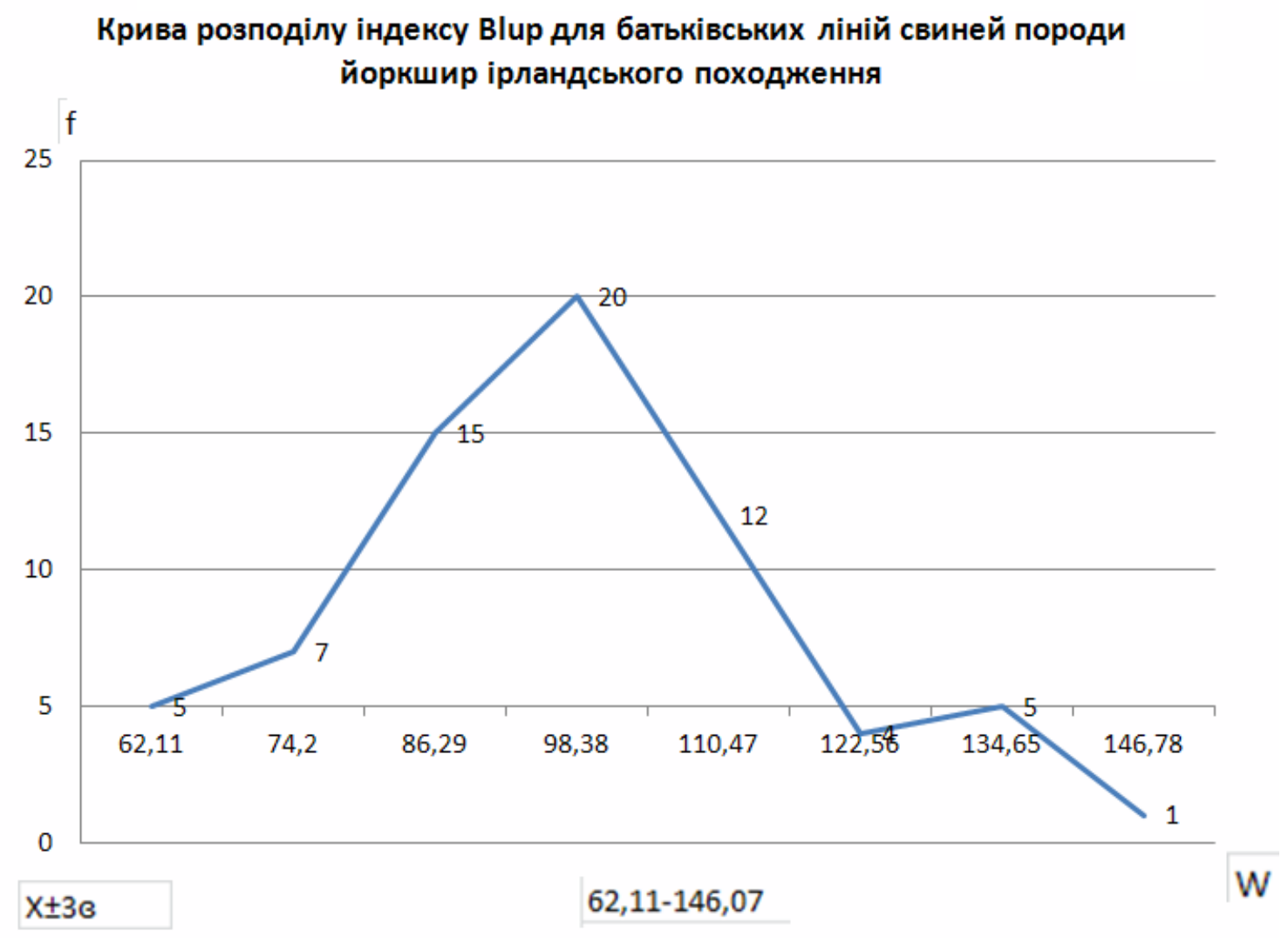

Крива розподілу індексу Blup для материнських ліній свиней f породи йоркшир ірландського походження

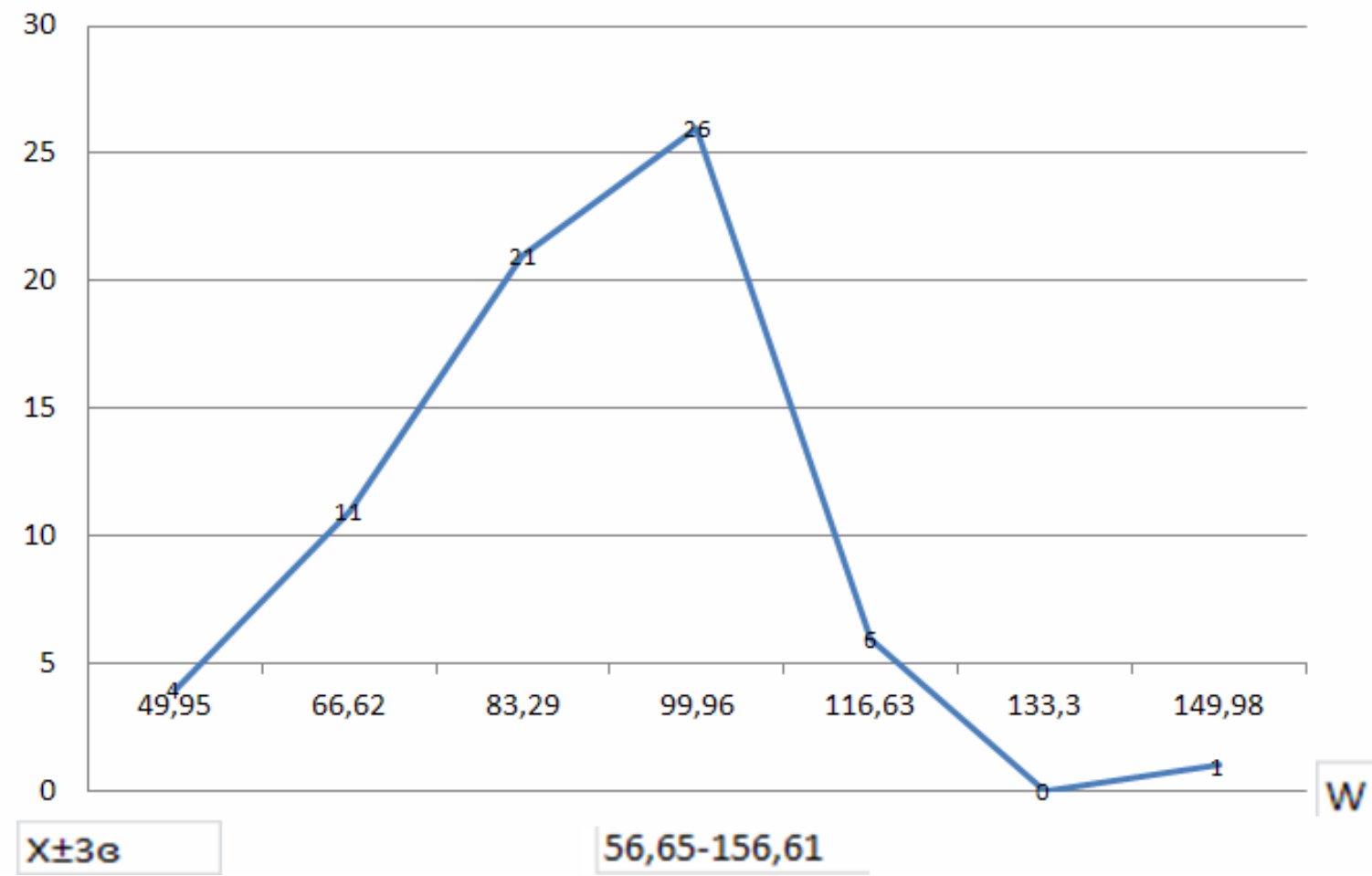

Distribution curve of the BLUP index (maternal lines) of the breed of Yorkshire Irish origin 
Thus, the findings of the earlier made by the animals on tribal values are partly confirmed the absence of a difference between conventional genealogy groups.

It is also noted that the frequency distribution curve of the BLUP index (maternal lines) has a more asymmetric character than the BLUP curve (parent lines). This fact is explained by the fact that, in order to calculate the integrated indicator of the BLUP, for boars and sows, different performance indicators, according to the existing requirements, are used. However, it should be noted that the subordination of the frequency distribution of the BLUP index (parent and parent lines) of the Gauss curve indicates the possibility of conducting a breeding process with a livestock for this size.

It is known that improvement of meat qualities of pigs at the present stage of development of the industry is related to the evaluation of animals of the main herd in the quality of offspring, and secondly, the introduction of the index methodology in the system of evaluation of meat qualities in pigs [2]. In the Meat Factory "Alan" a control slaughter of the descendants of the yoke breeds and dams was carried out. Characteristics of carcass quality and meat production level of animals are given in Table. 1, 2.

\section{Characteristics of the pig carcass quality Yorkshire breeds of Irish origin at the slaughter of live animals weighing $88-102 \mathrm{~kg}(\mathrm{n}=28)$}

\begin{tabular}{|l|l|l|}
\hline Carcase quality indicator & Average value & $\begin{array}{l}\text { Limit of this indicator of } \\
\text { carcass quality }\end{array}$ \\
\hline Length half mascara & & 93,2 \\
\hline Length of side of half mascara & 78,7 & $83-88$ \\
\hline Cervical vertebrae & 6,4 & $7-6$ \\
\hline Breast section & 15,3 & $16-15$ \\
\hline Lumbar section & 6,3 & $7-5$ \\
\hline Sacrum & 6,5 & $8-5$ \\
\hline Front width half-width & 32,1 & $35-30$ \\
\hline Back & 23,4 & $28-20$ \\
\hline The thickness of the spy on the back & & \\
\hline Above the withers & 28,6 & $35-18$ \\
\hline Over 6-7 vertebrae & 22,7 & $28-17$ \\
\hline Over the last edge & 23,7 & $38-16$ \\
\hline On average, on ice & 13,78 & $17,7-8,7$ \\
\hline Thickness of spit on the belly, mm & & \\
\hline 10 cm from the mosquito process & 7,0 & $14-5$ \\
\hline in 5 cm from the last nipple & 27,7 & $32-15$ \\
\hline Under the last edge & 20,0 & $35-10$ \\
\hline The balance of carcasses & 1,79 & $1,57-1,11$ \\
\hline Alignment of the spin layer on the back, $\%$ & 87,18 & $94,7-83,4$ \\
\hline
\end{tabular}

Analysis of the data obtained during the research (Table 1) shows that in the presence of high mean values of pig meat productivity indicators, which are defined according to requirements [3], the limits of the indicators have the character of "polarity". And this, in turn, only emphasizes the level of non-selectivity of the genotype according to these parameters and necessitates the development of a more objective approach to determining the quality of carcasses [5, 6]. In tabl. 2 contain materials on the morphological composition of the right hemisphere of the Yorkshire breed pigs. 
2. Morphological composition of the right half carcass of breeds of Yorkshire of Irish origin $(n=5)$

\begin{tabular}{|c|c|c|c|c|c|c|c|c|c|c|c|c|c|c|}
\hline \multirow{4}{*}{$\begin{array}{l}\text { Total pre- } \\
\text { slaughter } \\
\text { live weight } \\
\text { of pigs, kg }\end{array}$} & \multirow{4}{*}{ 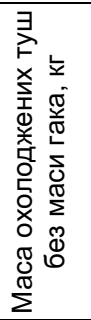 } & \multirow{4}{*}{ 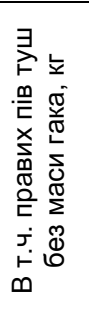 } & \multicolumn{12}{|c|}{ Morphological composition carcass kg /\% } \\
\hline & & & \multicolumn{4}{|c|}{ front part } & \multicolumn{4}{|c|}{ middle part } & \multicolumn{4}{|c|}{ back part } \\
\hline & & & \multirow{2}{*}{ 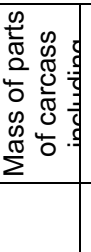 } & \multicolumn{3}{|c|}{ including } & \multirow{2}{*}{ 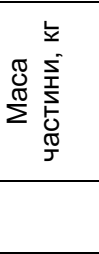 } & \multicolumn{3}{|c|}{ including } & \multirow{2}{*}{ 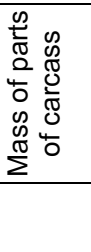 } & \multicolumn{3}{|c|}{ including } \\
\hline & & & & meat & $\begin{array}{c}\text { Fat + } \\
\text { skin }\end{array}$ & $\begin{array}{c}\text { кістк } \\
\text { и }\end{array}$ & & $\begin{array}{c}\text { mea } \\
\mathrm{t}\end{array}$ & $\begin{array}{l}\text { Fat + } \\
\text { skin }\end{array}$ & $\begin{array}{c}\text { кістк } \\
\text { и }\end{array}$ & & $\begin{array}{c}\text { mea } \\
\mathrm{t}\end{array}$ & $\begin{array}{c}\text { Fat + } \\
\text { skin }\end{array}$ & $\begin{array}{l}\text { bone } \\
\text { skin }\end{array}$ \\
\hline 509 & 358,4 & 179,6 & 58,2 & 39 & 10,4 & 8,8 & 60,2 & 35 & 14,8 & 10,4 & 61,2 & 44,0 & 9,0 & 8,2 \\
\hline $\begin{array}{c}\text { Specific } \\
\text { gravity of } \\
\text { the carcass }\end{array}$ & 100 & 100 & $\begin{array}{c}32,3 \\
3\end{array}$ & - & - & - & 33,56 & - & - & - & 34,11 & - & - & - \\
\hline $\begin{array}{c}\text { \% of raw } \\
\text { material } \\
\text { part }\end{array}$ & & & 100 & 67,0 & 17,9 & 15,1 & 100 & 58,1 & 24,6 & 17,3 & 100 & 71,9 & 14,7 & 13,4 \\
\hline
\end{tabular}

It was established that the ratio of meat: bone $(n=5)$ in different parts of the carcass was different, and on average it was 4,31: 1 , including:

The front part (cervical and shoulder-patch) - 4,43: 1; middle part (middle and lumbar) - 3,37: 1; the back (the back or the ham) $-5.37: 1$; inner fat half mascara $=2 \mathrm{~kg}$. The technological error on the scales in the raw material shop of the meat-packing plant is $0,2 \mathrm{~kg}$

The experimental data we receive show a different level of ossification of the portions of the semicircle, therefore they are characterized by a different commercial attractiveness and technological value. Thus, the ratio of "meat : spider" as a whole was $3,45: 1$, including the front part of the semicircle $-3,75: 1$, the middle part of the halfheath $-2,36: 1$, the posterior part of the semicircle 4,88: 1 .

Questions about the quality of the carcass in pigs and the selection evaluation of its parts were covered in his works in 1910 by E. A. Bogdanov [1]. But one should determine that the relevance of this issue for breeding work with pigs has not decreased to the present [12, 13-17].

So, in the 50th years of the last century Kh.R. Davidson, with his studies of the English pork market, has shown the different commercial appeal of individual parts (cuttings) of the semidine, which is the basis for building a qualitative breeding process with pigs in Ukraine, as is done in the UK.

At the same time, the British researcher of this issue noted that the most attractive in the consumer market of pork in the country are such valuable pieces of meat from the carcass as: the edge of the ankle, thick fillet, lumbar and therefore their price per 1 pound of raw material cost is almost twice the selling price of such parts as the carcass side, the thin and thick flaps, the cervical part and the shoulder blade with a handle.

We believe that at present the question of restoration as a bonite indicator of the "mass of the carcass of the rear one" is currently relevant, which, in our opinion, was unjustifiably excluded from the list of signs that characterize the meat productivity of the animal. It should be noted that for the breeding assessment of animals for meat productivity, this attribute is no less important than the length of the carcass or thickness of the spit at the level of 6-7 thoracic vertebrae.

The experimental data obtained by us confirm that the specific share of raw material losses after cooling is an average of $2.18 \%$ with limits of $2,03-2,52 \%$. The total yield of cooled carcass was $70,4 \%$. The leveling of the spin layer on the back was determined by the author's formula LS $=100 \%-S v$ and it was $87,18 \pm 0,183 \%$, which corresponds to an average level at the $90,48-83,64 \%$ signs (mean and low result). In order to calculate the carcass index (IT), the following formula was used:

$$
\mathrm{IT}=\frac{\mathrm{C} \Pi \Pi \times 3_{\mathrm{5}}}{\mathrm{T}_{\text {шா }} \times \mathrm{B}_{\mathrm{H}}}
$$


where СПП - the average calculated lifetime increment of products (raw materials) of a cooled carcass; $3_{6}$ balance of carcasses, units of index .; $\mathrm{T}_{\text {шп }}$ - average thickness of the spin at the 4 control points on the back (fork, 6-7 thoracic vertebra, at the level of the last rib and on the average on the hips), $B_{H}$ - the spin leveling on the back. The average index of the carcass in the experiment was $25,44 \pm 1,065$ at the limit of the sign 19,3-32,1 index units and variability of $8,37 \%$.

The correlation coefficient between the carcass index and the output of meat in the carcass was, in our case, unlikely and insignificant in the meaning that we explain the absence of the breeding process on this basis and the small amount of experimental material on the results of the collapse of the right hemisphere.

\section{Conclusions}

1. Classification of pigs by methodology Zavadovsky M.M. is not effective for breeding process in modern conditions.

2. The appropriateness of the use of the index method for determining the total breeding value of pigs and certain characteristics of their productivity has been confirmed.

3. In order to deepen breeding work with livestock, aimed at increasing meatiness of pigs, the method of ball scores for carcass quality is more objective than currently available in the industry «Instructions for boning pigs» and DSTU 71582010 "Pork meat in carcasses and half-goose".

\section{Bibliography}

1. Bohdanov E.A. Otkarmlyvanye sel'skokhozyaystvennyh zhyvotnyh /E.A. Bohdanov.- Moskva: Yzd. T-va «Ahronom», 1911.s.377-388

2. Kravchenko O.I. Otsinka yakosti tushi v Ukrayini: realiyi ta perspektyva /O.I. Kravchenko, A.A. Hetya.Kyyiv: Efektyvne tvarynnytstvo, 2010. - s.20-23.-(vyp.. \#2(42)

3. M'yaso Svynyna v tushakh i pivtushakh Tekhnichni umovy: DSTU 7158:2010.- [Chynnyy vid 01.01.2011]. K.: Derzhspozhyvstandart Ukrayiny 2011, 12 stor.

4. Kozlovskyy V.H. Plemennoe delo v svynovodstve N.H. Kozlovskyy, Yu.V. Lebedev y dr.- M.: Kolos, 1987.$272 \mathrm{~s}$.

5. Kudryavtsev P.N. Svynovodstvo SShA /P.N. Kudryavtsev, M.Y. Matyets.- M.: Yzdatel'stvo «Sel'skokhozyaystvennaya nauka y praktyka za rubezhom», 1968.-98 s.

6. Davydson Kh.R. Svynovodstvo (sokr. Perevod A.A. Fryd, L.P. Maksymov, pod. red. y s pred. E.Y. Symon). M., uzd. Y-L, 1956, s. 34

7. Hrudev D.Y. Orhanyzatsyya plemennoy rabotb v svynovodstve /D.Y. Hrudev. - Moskva: Yzd-vo MSKh RSFSR, 1963.-s.38

8. Osnovnye voprosy plemennoho dela. Pod red. Y.M. Kudryavtseva, Y.Y. Podvoyskoho /vyst. N.A. Kravchenko na VII plenume sektsyy zhyvotnovodstva po voprosam plemennoho dela ot 23-30 yanvarya $1953 \mathrm{~h}$. s.170-177

9. Problemy svynovodstva Rossyy posle vstuplenyya v VTO/Yu. Kovalev. w.w.w. exima.ru

10. Analyz deystvuyushchykh system y puty reshenyya stratehycheskykh zadach po sovershenstvovanyyu henetycheskoho obespechenyya rossyyskoho svynovodstva /w.w.w. nsgc.ru

11. Instruktsiya z bonituvannya svyney. K.: VPTs «Kyyivs'kyy universytet», 2003.- $64 \mathrm{~s}$.

12. Lakyn H.F. Byometryya. Uchebnoe posobye dlya byoloh. spets. Vuzov. - 3-e yzd. Pererab. y dop. - M: Vysshaya shkola, 1980.-293.

13. Kravchenko O. Perspektyvy zastosuvannya suchasnoyi systemy otsinky tush svyney na myasokombinatakh Ukrayiny/ O.Kravchenko, A.Hetya, R. Shrayver, M.Chemezov. - K.: Prybutkove svynarstvo, 2016. - S.52-55. 
14. From farm to folk. Safe food for Europe's consumers/European commission. - Luxembourg: Office for Official Publications of the EC. - 2004. 22p.

15. Gispert M. Pig carcass grading/Report at the workshop in the frame of EU SSA "Young-Train" held in IRTA-CTC Monels. - 8-11.05.2006.

16. Remuneration au TMP/Convention des COMITE REGIONAL PORCIN et L'UNINON BRETONNE DES ABATTEURS DE PORCS du 14 december 2006.

17. Ventes au classement/Convention des FEDERATION ACHETEURS AU CADRAN, COMITE REGIONAL PORCIN, UNIPORC OUEST, MARCHE DU PORC BRETON et L'UNINON BRETONNE DES ABATTEURS DE PORCS du 14 december 2006.

18. 32009D0622 2009/622/EC: Commission Decision of 20 August 2009 authorising methods for grading pig carcases in Slovakia (notifield under document C (2009) G389). 